\title{
COMPETING PROFESSIONAL KNOWLEDGE CLAIMS ABOUT MENTAL CAPACITY IN THE COURT OF PROTECTION
}

Dr Jaime Lindsey, University of Essex

Summary: This article analyses the role of evidence in resolving Court of Protection proceedings, drawing on qualitative data obtained from observations of the Court of Protection, a review of Court of Protection case files and interviews with social workers. It is argued that there is a hierarchy of professional evidence in mental capacity law. Psychiatric evidence is at the top of this hierarchy whereas social work evidence is viewed as a less persuasive form of knowledge about mental capacity. The article argues that this is because mental capacity law views psychiatric evidence as a form of objective and technical expertise about capacity whereas social work evidence is viewed as a form of subjective, experiential knowledge. In challenging this hierarchy, it is instead argued that mental capacity law should place greater weight on experiential knowledge emanating from a relationship with the subject of the proceedings, rather than elevating the status of psychiatric evidence about mental capacity.

Keywords: Court of Protection, evidence, expertise, knowledge, mental capacity, psychiatry

\section{INTRODUCTION}

Decisions about a person's mental capacity under the Mental Capacity Act 2005 (MCA) centre on the presentation of evidence in the Court of Protection (CoP), the court that deals with disputes under the MCA. Where parties disagree about whether or not a person (usually referred to as ' $\mathrm{P}$ ') has capacity, an expert will often be appointed to provide an opinion. Medical experts are commonly used but not exclusively so. Under a previous Practice Direction (declaratory proceedings: incapacitated adults) [2002] 1 All ER 794 annex A, it was stated that '[e]vidence from a psychiatrist or psychologist who has assessed the patient . . . is generally 
required' but now the law makes clear that psychiatric evidence is not always necessary. ${ }^{1}$ In this article, I show that there is a hierarchy of professional evidence in mental capacity law, with psychiatric evidence dominating and evidence from others, such as social workers, having less influence. This hierarchy underlines concerns about the medicalisation of mental capacity law ${ }^{2}$ and suggests that law's deference to medical professionals remains entrenched despite developments post-Bolam. ${ }^{3}$ I argue that this hierarchy of evidence exists because psychiatric evidence is treated by participants in mental capacity law as a form of objective expertise whereas social work evidence is viewed in more subjective, experiential terms.

When referring to 'knowledge' claims throughout this article I mean a claim to represent the reality or truth of a situation. I understand a reliable knowledge claim to be one that has a persuasive claim to represent truths or, more likely, partial truths ${ }^{4}$ about phenomena. In this sense a reliable knowledge claim is a claim to objectivity, albeit such claims are always constrained by a range of factors such as bodies, resources and linguistic practices, which impact on the availability of accurate knowledge. I develop this understanding of knowledge to consider the way that mental capacity law accepts psychiatric knowledge as expertise and discounts knowledge drawn from other professional experience, such as social work evidence. By discounting experiential knowledge the CoP bases its decisions about mental capacity on a narrower range of (often psychiatric) evidence. Yet this preference for psychiatric knowledge is often not in the interests of $P$. For example, only a limited number of psychiatrists have the relevant experience and willingness to prepare reports alongside their daily clinical work,

\footnotetext{
$1 G v E$ [2010] EWCA Civ 822 para 61.

2 This has been recognised by others in relation to other areas of medical ethics see $\mathrm{M}$ Brazier and $\mathrm{J}$ Miola (2000) 'Bye-bye Bolam: A Medical Litigation Revolution?' 8 Medical Law Review. 85. In relation to mental capacity, Case argues that there remains evidence of judicial deference in reported judgments, see P Case, (2016) 'Negotiating the domain of mental capacity: Clinical judgement or judicial diagnosis?' 16 Medical Law International 174.

${ }^{3}$ For example post developments in both Bolitho $v$ City and Hackney Health Authority [1998] A.C. 232 and Montgomery $v$ Lanarkshire Health Board [2015] UKSC 11, see also C Foster and J Miola, (2015) 'Who's in charge? The relationship between medical law, medical ethics, and medical morality?' 23 Medical Law Review 505 and S Devaney and S Holm (2018) 'The transmutation of deference in medicine; An ethico-legal perspective' 26 Medical Law Review 202.

4 M Harris, 'Anthropology and Postmodernism' in MF Murphy and ML Margolis (eds), Science, Materialism and the Study of Culture (University Press of Florida 1995).
} 
meaning that the same experts are used repeatedly. ${ }^{5}$ The over-reliance on psychiatric experts can create delays in cases reaching a conclusion and also 'include the possibility that the precepts of psychiatry and medicine may work against the statutory presumption of capacity'. ${ }^{6}$

The article makes these arguments based on data from an empirical study for which I observed eight CoP cases over 11 hearings, reviewed 20 CoP case files and carried out eight in depth interviews with social workers. The CoP makes decisions about a person's mental capacity and, if they are found to lack capacity, then the court can make certain decisions in their best interests. Most often cases are brought to the CoP where there is a dispute between the parties, whether that be P, P's family members and/or health and social care professionals. This is one of the first published studies using empirical data obtained from accessing the CoP, ${ }^{7}$ with the court only recently opening up access, having been a private court for a number of years. ${ }^{8}$ This research therefore contributes to the increasing transparency of the CoP, which has increased efforts in this regard in recent years. The qualitative data obtained has been analysed to consider the role of psychiatric and social work evidence in CoP proceedings, going beyond the information recorded in publicly accessible judgments.

Before setting out the methods used, the article starts with a discussion of the role of expert and experiential evidence in CoP proceedings. Following discussion of the nature of knowledge and expertise, I use the data obtained and reported case law to argue that there is a hierarchy of evidence in mental capacity law, with psychiatric evidence being attributed greater authority than the evidence of social workers. In the following section I set out the reasons underpinning this hierarchy, arguing that psychiatric evidence is treated by participants in mental capacity law as a form of objective expertise whereas social work

\footnotetext{
${ }^{5} \mathrm{P}$ Case (n2).

6 Ibid, 199.

${ }^{7} \mathrm{~L}$ Series, P Fennell and J Doughty, The Participation of $P$ in Welfare Cases in the Court of Protection (Cardiff 2017), L Series, P Fennell, J Doughty and A Mercer, Welfare cases in the Court of Protection: A statistical overview (Cardiff 2017), J Lindsey, (Forthcoming), 'Testimonial Injustice and Vulnerability: A qualitative analysis of participation in the Court of Protection', Social and Legal Studies.

8 Initially the rules changed to make the CoP more transparent via the Court of Protection Practice Direction - Transparency Pilot. The transparency changes were made permanent in the Court of Protection Rules 2017 (CoPr).
} 
evidence is viewed in more subjective, experiential terms. I criticise this characterisation, arguing that psychiatric evidence is often highly subjective yet framed in technical, clinical and objective language. In the final section, a relational approach to assessing capacity is advanced, which values the experiential knowledge of those professionals who have a relationship with $\mathrm{P}$. In particular, my contribution to debates around reform include that capacity should be assessed by a professional who has an established relationship with $\mathrm{P}$ as this is more likely to be facilitative of P's capacity.

\section{CONTEXT: PROFESSIONAL EVIDENCE IN THE COURT OF PROTECTION}

Evidence is central to legal decisions. Yet the reliability of evidence varies depending on the knowledge of the evidence giver. In this section I discuss the role of professional evidence in the CoP and consider how different ways of understanding knowledge help us to understand evidence. Knowledge can be based on technical expertise, experience or, more often, a combination of both. Yet in the CoP, the focus is explicitly on expert evidence rather than experiential evidence and, moreover, experts who can provide an 'objective, unbiased opinion'. 9

\section{Requirements for expert evidence}

In the CoP, expert evidence is used to help judges make decisions about mental (in)capacity. According to the Court of Protection rules 2017, expert evidence is restricted to that which is 'necessary to assist the court to resolve the issues in the proceedings'. ${ }^{10}$ An expert is appointed to provide an 'objective, unbiased opinion on matters within the expert's expertise, and should not assume the role of an advocate. ${ }^{11}$ There is no detail on which types of expert

\footnotetext{
${ }^{9}$ CoPr PD 15A.

${ }^{10}$ CoPr 15.3 .

${ }^{11}$ CoPr PD 15A.
} 
should be used, but case law suggests that there is no requirement for a capacity assessment to be carried out by a person with psychiatric or other specific medical expertise. ${ }^{12}$ For example in A Local Authority $v$ SY Keehan J stated: ${ }^{13}$

I am told by counsel that it is more usual for the assessment of capacity to be undertaken by a medical practitioner or a psychiatrist. The assessment in this case demonstrates that an appropriately qualified social worker is eminently suited to undertake such capacity assessments.

Despite this legal position, in practice medical professionals are more likely to be used as expert witnesses about capacity. ${ }^{14}$ Donnelly, for example, explains that '[c]ourts have long relied heavily on expert medical evidence regarding capacity'. ${ }^{15}$ Yet as this reliance is not required by case law or statute, I analyse the different knowledge claims that underpin professional evidence to examine why medical (specifically psychiatric) experts still dominate mental capacity law. Whilst the rhetoric of mental capacity law is that any professional can provide expert evidence on capacity, in practice CoP judges still attribute greater authority to medical (more particularly psychiatric) evidence. ${ }^{16}$

'Expert knowledge' is used to describe a form of specialist knowledge. ${ }^{17}$ Whilst there may be various sub-categories of expertise such as contributory or interactional, ${ }^{18}$ I focus on

\footnotetext{
12 G v E [2010] EWCA Civ 822 para 61.

13 [2013] EWCOP 3485 para 22.

${ }^{14}$ See Table one which provides an insight into the evidence used in the sample of cases that I obtained. An analysis of case law also supports this argument as in many cases judges refer to the 'medical' or 'clinical' evidence on capacity, for example see PH v A Local Authority [2011] EWHC 104 and CS (Termination of Pregnancy) [2016] EWCOP 10. This is also reinforced by other analyses of evidence in the CoP, see P Case (n2).

${ }^{15}$ M Donnelly, (2009) 'Capacity assessment under the Mental Capacity Act 2005: Delivering on the functional approach?' 29 Legal Studies 464, 469.

${ }^{16} \mathrm{P}$ Skowron (Forthcoming) 'The relationship between autonomy and adult mental capacity in the law of England and Wales' Medical Law Review.

17 For further discussion of expert evidence in the law see D Dwyer, The judicial assessment of expert evidence (Cambridge University Press 2008).

${ }^{18} \mathrm{H}$ Collins and R Evans, (2002) 'The Third Wave of Science Studies: Studies of Expertise and Experience' 32 Social Studies of Science 235 and H Collins and R Evans, Rethinking expertise (University of Chicago Press 2008).
} 
technical expert knowledge claims as these claims dominate expert evidence in legal proceedings. Expert knowledge claims are ultimately claims to objectivity; they are claims to likelihoods of truth informed by specialist knowledge that represents society's best understanding of phenomena. ${ }^{19} \mathrm{~A}$ claim to possessing objective knowledge is a claim to have knowledge that represents the likely truth of a situation that will, in turn, enable the court to make a decision based on reliable evidence from specialists in the field. However, all knowledge is, to varying degrees, constrained by our ability to understand information. Whether because the information available is incomplete, a lack of resources, personal factors or linguistic constraints, objective knowledge claims are more likely claims to partial truths ${ }^{20}$ about phenomena.

Courts rely on expert evidence to inform them about domains which are beyond their own expertise. ${ }^{21}$ That is why lawyers are generally not allowed to be expert witnesses as the judge is the expert in the law. An individual can gain specialist technical knowledge based on research, learning, skill or practice within a field. Even though expert knowledge is technical, that technical knowledge must also have been put into practice. For example, an experienced surgeon likely has an objectively reliable claim to possessing technical surgical expertise. This is because she has learned and practised the technical skills required to perform a specific task, which could also be performed by another should they learn the same skills. Technical expertise is, in many cases, a reliable form of objective knowledge because it is based on evidence of effectiveness, which can be replicated by others. However, knowledge treated by law as technical expertise is often founded upon highly subjective knowledge about the world. For example, McKenna and Graham argue that '[t]echnocratic discourse appears to be objective and rational because of its pseudoscientific appearance. But it is precisely the

\footnotetext{
${ }_{19}$ M Harris, 'Anthropology and Postmodernism' in MF Murphy and ML Margolis (eds), Science, Materialism and the Study of Culture (University Press of Florida 1995).

$20 \mathrm{lbid}$.

${ }^{21}$ For example, Dwyer highlights that expert evidence has three key features - it represents opinion rather than fact, it is the product of specialist knowledge and it is presented by witnesses who represent practice outside of the law, (n17), 75-76.
} 
opposite in most cases'. ${ }^{22}$ By this they mean that in using language that appears objective, the communicator can obscure the value judgements contained within. Whilst not always so, one effective way of persuading others is through the use of objective and scientific language. However, the content of what is being said must also stand up to scrutiny.

One of the ways law identifies expert knowledge is where the profession has historical legitimacy and support from professional bodies. ${ }^{23}$ This approach to expertise does not necessarily mean the knowledge claim is legitimately technical or objective, merely that it is one way that the law categorises knowledge as expertise. In seeking to rely on a new domain of expertise, as occurred with forensic psychiatry experts in criminal trials, ${ }^{24}$ the party would have to convince the court this was necessary to help resolve the dispute. Yet in cases such as these, where law defers to expertise, it often allows other professions with historical legitimacy to intervene instead..$^{25}$ This occurred in criminal trials where women who had been subjected to domestic abuse then killed their abusive partner. In those cases where law chose not to imprison the 'battered woman'26 it instead constructed their situation in 'psy' terms, meaning in ways constructed by professions that deal with the human mind including psychiatry, psychology and psychotherapy. As a result of this 'psy' construction, the law did not punish the women in question through imprisonment but instead required them to undergo

\footnotetext{
22 BJ McKenna and P Graham, (2000) 'Technocratic Discourse: A Primer' 30 Journal of Technical Writing and Communication 223, 224.

${ }^{23}$ See list of specialities: British Medical Association <https://www.bma.org.uk/advice/career/studyingmedicine/insiders-guide-to-medical-specialties/nhs-career-choices> accessed 14 June 2018 and General Medical Council <https://www.gmc-uk.org/education/standards-guidance-andcurricula/curricula> accessed 14 June 2018.

${ }^{24}$ A Loughlan and T Ward, (2014) 'Emergent Authority and Expert Knowledge: Psychiatry and Criminal Responsibility in the UK' 37 International Journal of Law and Psychiatry 25.

${ }^{25}$ C Smart, Feminism and the Power of Law (Routledge 1989).

26 LE Walker, The Battered Woman Syndrome (Springer 2009).
} 
psychiatric treatment. ${ }^{27}$ This highlights law's role in deciding who can be recognised as an expert and law has a history of deference to medicine in this regard..$^{28}$

The role of deference is particularly relevant to the way that law receives medical evidence. Bolam centred on the expertise of diagnosis and treatment, with the judge directing that a man 'is not guilty of negligence if he has acted in accordance with a practice accepted as proper by a responsible body of medical men skilled in that particular art. ${ }^{29}$ Whilst this approach has been modified, ${ }^{30}$ it still represents the cornerstone of how medical (and other) expertise is received by law and has extended beyond the traditional domain of diagnosis and treatment through 'Bolamisation'. ${ }^{31}$ As described by Brazier and Miola, Bolamisation is the phenomenon that deference to the medical profession expands beyond the core of medical expertise to non-clinical issues. I suggest throughout that Bolamisation is present in the mental capacity context, which contributes to the dominance of psychiatric experts. Medical expertise is arguably required about mental capacity if it is accepted that a diagnosis is required under the section 2 MCA requirement of 'an impairment of, or disturbance in, the functioning of the mind or brain' ${ }^{32}$ In this regard, the article contributes to wider debates about the operation of the MCA, specifically that section 2 MCA need not be interpreted as a diagnostic test, which, in turn, should lead to less reliance on medical evidence. However, in relation to section 3 MCA, the legitimate role of medical expertise is less apparent. This 'functional' aspect of the test requires that the person understands the information relevant to the decision, ${ }^{33}$ is able to

\footnotetext{
${ }^{27}$ For an exploration of the role of 'psy' professionals and their relationship with law see: C Smart, Feminism and the Power of Law, Armstrong, I (1999) 'Women and their 'uncontrollable impulses': The medicalisation of women's crime and differential gender sentencing' 6 Psychiatry, Psychology and Law 67.

${ }^{28}$ Perhaps the most well-known example of this is Bolam v Friern Hospital Management Committee [1957] 1 WLR 582 but the relationship between law and medicine goes back much further, see MB Kapp, (1985) 'Medicine and law. A symbiotic relationship?' 78 The American Journal of Medicine 903 and for a more recent analysis see Devaney and Holm (n3).

${ }^{29}$ Bolam v Friern Hospital Management Committee [1957] 1 W.L.R. 582, 587.

30 For example by Bolitho $v$ City and Hackney Health Authority [1998] A.C. 232.

${ }^{31}$ M Brazier and J Miola (n2) and C Foster and J Miola (n3).

32 This would most likely be adduced from a psychiatrist, but medical experts in other areas might also be relevant, such as neurology or gerontology.

${ }^{33}$ MCA s3(1)(a).
} 
retain that information, ${ }^{34}$ use or weigh it as part of the decision-making process, ${ }^{35}$ is able to communicate the decision ${ }^{36}$ and appreciate the reasonably foreseeable consequences of the decision. ${ }^{37}$ These issues, it is later argued, require a more holistic understanding of the individual and how they make decisions, rather than 'objective, unbiased' expertise as outlined in the CoPr.

\section{The role of evidence from experience}

By contrast, experiential knowledge refers to knowledge gained form a person's individual experiences. It emanates from a person's perception of things and, in the professional context, this perception comes from professional experience. Having experience does not automatically equate to having knowledge, but experience can underpin a knowledge claim by providing an increased understanding of phenomena. ${ }^{38} \mathrm{~A}$ knowledge claim based on experience need not possess evidential certainty to be reliable but should still have 'sufficient rigour for proceeding'. ${ }^{39}$ This means that a reliable experiential knowledge claim must have some basis in reality, rather than being an untruth, for example as proven by a more objective source such as an image recording that contradicts the person's account.

Evidence given in legal proceedings based on personal experience is often viewed as a less persuasive knowledge claim than expert knowledge, albeit it may have strong rhetorical value. For example, despite strong rhetoric in some cases that the person's views should be paramount, ${ }^{40}$ it is still common for best interests decisions to be taken which go against the expressed wishes of P. However, evidence from professional experience may have a stronger knowledge claim than evidence from personal experience. For example, in the CoP a

\footnotetext{
${ }^{34}$ MCA s3(1)(b).

${ }^{35}$ MCA s3(1)(c).

${ }^{36}$ MCA s3(1)(d).

${ }^{37}$ MCA s3(4).

${ }^{38} \mathrm{H}$ Collins and R Evans (n18).

${ }^{39}$ M Lee, (2017) 'Knowledge and landscape in wind energy planning' 37 Legal Studies 3, 12.

40 Aintree University Hospitals NHS Foundation Trust $v$ James [2013] UKSC 67, Wye Valley NHS Trust $v B$ [2015] EWCOP 60
} 
professional who can draw on their experience of working with $\mathrm{P}$ might be able to provide more informed examples of P's capacity. This is indirectly reflected in the quote from the $S Y$ case noted above as SY's social worker was able to provide 'a full, detailed and helpful assessment' of her capacity, ${ }^{41}$ which was likely based on the social worker's detailed experiential knowledge of SY.

Professional experiential knowledge is gained from the individual's personal interaction with the world but relates to matters in their professional lives for which they may also have professional certification. Evidence from professional experience is distinct from technical knowledge as it relies heavily on professional judgement. ${ }^{42}$ Part of professional experiential knowledge is therefore having the experience to make judgement calls. Making the right professional judgement call is often based on the individual's own experiences and insights rather than on objective criteria. Social workers, for example, draw on their professional judgement about what works in a given case, rather than advancing an obviously technical solution such as the use of particular medication or other 'treatment'. In this respect social workers can provide evidence on a wider range of factors than a medical professional might have in relation to a specific patient. However, it may be more difficult for social workers to couch this judgement in the objective or technical 'psy' language.

Experiential knowledge may be less persuasive in the legal context because it is viewed to be more subjective than technical expertise. Yet as Skowron explains in respect of evidence about best interests: ${ }^{43}$

Attention to subjectivity increases the likelihood of a person's wishes determining their objective best interests, for considering things from the person's point of view tends to make their wishes central, instead of merely one view among many.

\footnotetext{
41 [2013] EWCOP 3485 para 21.

$42 \mathrm{M}$ Lee (n39).

${ }^{43} \mathrm{P}$ Skowron (n16), 18.
} 
This argument applies to professional evidence about capacity too. Having a professional provide an experiential account of $\mathrm{P}$ can contribute to the court's 'objective' determination of whether or not $\mathrm{P}$ has capacity. Knowledge gained from experience of $\mathrm{P}$ can enable the professional to provide more realistic examples to strengthen their conclusions on capacity, based on an understanding of P's life. Reciting abstract technical knowledge should be less persuasive than hearing the professional describe their experiences of observing P's decisionmaking in real life situations, or of having attempted different ways of facilitating P's capacity in practice. Similarly, having technical knowledge of the aetiology of a particular mental illness is less likely to be effective for a patient if the psychiatrist lacks experience of how to deal with that condition in practice. However, as I argue throughout, mental capacity law emphasises the objective, technical aspects of psychiatric expertise and discounts social work knowledge because it is characterised in subjective and experiential terms.

\section{METHODS}

In undertaking empirical research in this area, my aim was to explore how mental capacity law worked in practice rather than solely analysing legislation and case law. I specifically sought to investigate the role of evidence in mental capacity law proceedings, given the determinative role that evidence plays in resolving legal disputes. Whilst reported judgments are available, not all cases are reported and, furthermore, judgments include the information selected by the judge rather than necessarily reflecting all of the evidence. The three methods used for this research were: interviews with social workers, review of CoP case files and observations of CoP hearings. Eight in depth interviews were carried out with social workers who had experience of working with the MCA. These interviews were carried out to explore social workers' perceptions of mental capacity law, their understandings of capacity assessments and when they take cases to the CoP. Social workers were selected because the vast majority 
of cases in this context, ${ }^{44}$ perhaps in contrast to medical treatment cases, are brought to court by local authorities and social workers will therefore be at the centre of many of those decisions.

A review of $20 \mathrm{CoP}$ case files was also carried out alongside observations of eight cases over 11 hearings. The subject matter of the cases concerned capacity to consent to sex, capacity to marry and capacity to decide on contact with others. The CoP aspect of the research was approved by the Vice President of the CoP, Her Majesty's Courts and Tribunals Service and the Ministry of Justice to commence from November 2015 and the research ended in December 2016. I was granted a privileged access agreement by the Ministry of Justice to access case files and observe case hearings. This agreement required that all information recorded was anonymised. The qualitative data collection at the CoP was one of the first research projects of its kind, with the CoP only recently opening up access to researchers and the public. It therefore provides an original insight to CoP cases, most of which remain unreported at the date of publication of this article. The research was given ethical approval by the University of Birmingham Research Ethics Committee and all references to names and initials in this article are anonymised and do not reflect the actual names of any participants in the research.

The key findings of the research include four main conclusions. First, that mental capacity law was used as a tool for dealing with abuse because of weaknesses in the legal framework for adult safeguarding. Second, that mental capacity law reinforces a model of inherent vulnerability, usually perceiving $P$ to be vulnerable because of her disability rather than for situational reasons. Third, the research concluded that $P$ does not participate sufficiently in COP proceedings. ${ }^{45}$ Finally, the research concluded that greater weight is placed on psychiatric evidence in mental capacity law rather than on the evidence of other professionals. This latter finding is the focus of this article.

\footnotetext{
${ }^{44}$ The context I refer to is welfare cases rather than medical treatment cases. In the latter, NHS Trusts are more likely to be involved than local authorities.

$45 \mathrm{~J}$ Lindsey (n7).
} 


\section{THE HIERARCHY OF EVIDENCE IN MENTAL CAPACITY LAW}

In this section I show that there is a hierarchy of evidence in mental capacity law. I focus on the status of psychiatric evidence contrasted with social work evidence. My data suggested that psychiatric evidence had greater authority than the evidence of others such as social workers. This is noteworthy because the way that the CoP treats evidence on capacity is likely to have a 'trickle-down' effect on capacity assessments carried out outside of legal proceedings. By this I mean that if experiential evidence is devalued by the $\mathrm{CoP}$, then it is also likely to be devalued in non-legal settings. It is therefore important to acknowledge the prospect of law-making not being confined to the CoP but also to those (usually psychiatric) experts who have the authority to shape capacity judgements outside of formal legal processes through 'hidden law-making' ${ }^{46}$

These data also show that psychiatric evidence had a higher evidential status than social work evidence, despite judicial rhetoric to the contrary. ${ }^{47}$ For example, one social worker, David, summed up the experiences of my social work interviewees. He told me about a case where he said he was really proud of his preparation but that when it came down to doing the capacity assessment:

l'd gone out with a consultant psychiatrist and looked at what l'd got and he said no don't worry about that I'm gonna do it, so that was a bit irritating... it was the department's responsibility to follow the law in relation to this vulnerable chap but obviously it was then deemed that the health professional

\footnotetext{
$46 \mathrm{~J}$ Montgomery, C Jones and H Biggs, (2014) 'Hidden Law-Making in the Province of Medical Jurisprudence' 77 Modern Law Review 343.

47 A Local Authority v SY [2013] EWCOP 3485 para 22.
} 
would be more senior and more expert than I would in assessing capacity... so he did the assessment, which I was quite frustrated about. [David]. ${ }^{48}$

This was reinforced in the CoP case files. As outlined in Table One, the highest proportion $(n=6)$ contained independent expert reports from psychiatrists. This reflects analysis of reported CoP judgments, for example Case found that $73 \%$ of witnesses providing expert evidence on capacity were medical professionals, $55 \%$ of whom were psychiatrists. ${ }^{49}$ Furthermore, in a number of cases, even where $\mathrm{P}$ disagreed with the decision of the expert on capacity, her representative accepted the expert evidence and the case proceeded on the basis of agreement and deference to the expert opinion, for example T City Council $v$ CY (expert discipline unknown), $O D \vee R$ City Council (psychiatric report), $P$ County Council v (1) SE (2) TM (psychiatric report) and P CCG $\vee Q B$ (psychiatric report).

Three cases in my sample contained expert reports from clinical psychologists, highlighting that they were sometimes used instead of psychiatrists, despite the differences. For example, in $H$ County Council $v X C$, the judge, and XC's family, were unhappy with the amount of time that it was taking to conclude the matter and there was difficulty in locating an appropriate expert. There was already social work evidence on capacity but it was not perceived to be independent by XC's family. The judge urged the local authority to appoint an expert and my observational notes record that he stated 'all we need is somebody with expertise in LD [learning disabilities] with adults, huge no [number] of consultant psychiatrists with availability'. He went on to qualify this saying 'I promise you there are a huge number of experienced clinical psychologists available' and ultimately a clinical psychologist was instructed in that case. That the judge had to be so insistent on broadening the range of experts shows the engrained hierarchy in appointing psychiatric experts in the CoP. However,

\footnotetext{
${ }^{48}$ David was a qualified social worker with experience of working primarily with older adults with mental health needs.

49 P Case (n2), 185.
} 
the fact that he alternatively suggested a clinical psychologist rather than another professional highlights the preference for 'psy' expertise in relation to mental capacity.

Considering the CoP data further, Table One shows that there were two cases in which independent social work reports were obtained, albeit in both a doctor's report was also obtained. ${ }^{50}$ Social work evidence was predominantly used on the 'COP3' application to support the local authority's position on capacity rather than social workers being appointed as independent experts. The CoP has acknowledged that social workers can be recognised as expert witnesses ${ }^{51}$ but this is much less common and typically social workers provide evidence to support the application to the CoP and factual witness evidence. In the majority of cases, further evidence was then sought, usually from a psychiatrist, even though in all but one case the professionals reached the same conclusion on capacity. However, this observation is complicated by the issue of independence (discussed further below), as it could be argued that a social worker completing a COP3 form to bring the case to court has already made up their mind about capacity. It is therefore likely to be in P's interests to have an independent expert review the evidence in the hope that they will come to a different decision. Whilst persuasive in theory, I question whether this is the reason that social work evidence is devalued.

A review of recent case law indicates that appointing an independent expert may occur less frequently where the professional completing the COP3 application is a psychiatrist. For example, $R e Q Q^{52}$ concerned an application brought by a psychiatric hospital in relation to a 26 year old patient's capacity to make an advance decision and to decide on medical treatment. In that case Mr Justice Keehan explained:53

\footnotetext{
50 There is some evidence of a similar approach in reported case law as well, see London Borough of Redbridge $v$ G \& Ors [2014] EWCOP 485 where an independent psychiatrist and an independent social worker were both instructed.

51 LBL $v$ RYJ [2010] EWCOP 2665.

52 [2016] EWCOP 22.

53 para 3.
} 
Dr G, QQ's responsible and treating clinician for the last 12 months, has prepared three reports, which I have read, and she has given brief oral evidence before me today... Without hesitation I accept entirely the evidence of $\operatorname{Dr} \mathrm{G} .$.

There is no evidence from the judgment that an independent capacity assessment was obtained. Similarly, in $X \vee A$ Local Authority \& Anor ${ }^{4}$ capacity assessments were carried out by a psychiatrist and social worker prior to the case reaching the CoP. In the judgment, the psychiatrist's conclusions, that $X$ had capacity, were preferred over the evidence of the key social worker, who concluded that $\mathrm{X}$ lacked capacity. There appeared to be no independent expert instructed ${ }^{55}$ and the psychiatrist's evidence features throughout the judgment. These are not the only cases where the non-independent clinician's evidence was deferred to, ${ }^{56}$ indicating that deference to medical professionals persists in mental capacity law.

This was also reinforced by my data. In only one case, K County Council $v S L$, did the psychiatric evidence come to a completely different finding from the social work evidence, which questions the value in obtaining independent psychiatric reports. In that case the social worker's statement concluded that SL lacked the capacity to marry and to consent to sexual relations. The independent psychiatrist's initial view was that SL lacked the capacity to consent to sexual relations, and therefore marriage, but that because he was 'less certain in this case' than in most, he explained 'I would have to revise this opinion if a person [probably a woman speaking to her alone] was able to get her to describe the sexual act in simple terms and of the risks of infection'. The psychiatrist's subsequent report found that SL had gained capacity and proceedings were withdrawn. In one other case there was also a partial reversal of the

\footnotetext{
54 [2014] EWCOP 29.

${ }^{55}$ Albeit a s 49 MCA report was awaited, from the facts it seems this was to come from X's treating psychiatrist.

${ }^{56}$ See also AN NHS Trust $v$ A [2015] EWCOP 71 and Cambridge University Hospitals NHS Foundation Trust v BF [2016] EWCOP 26. Royal Free NHS Foundation Trust $v$ AB [2014] EWCOP 50 and Cheshire \& Wirral Partnership NHS Foundation Trust $v Z$ [2016] EWCOP 56 are both similar cases where the treating clinicians' evidence was given weight, albeit in both cases an opinion from another expert was also obtained.
} 
social worker's initial findings that $\mathrm{P}$ lacked capacity ( $K$ County Council $v \mathrm{MW})$. These data suggest that evidence from psychiatrists, and to a lesser extent clinical psychologists, was repeatedly adduced, even though in only one case did it completely overturn the original social work finding on capacity (and only following a period of educative work with P). This suggests that, even when reaching the same conclusion, evidence from psychiatrists is perceived to have greater authority.

This hierarchy was also clear from my observations of $Y$ County Council $v$ (1) LC (2) GK (3) SC. The case concerned LC, a woman in her early twenties described as having autism and a mild learning disability. LC had been in a three-year relationship with a man, GK, when proceedings commenced. During that time, LC and GK married without the knowledge of LC's family. LC lived with her mother and by all accounts had a close relationship with her. When LC's mother was informed of the marriage, she notified social services as she was concerned that the marriage was to enable GK to obtain a spousal visa to reside in the UK. The case before the CoP concerned LC's capacity to marry and consent to sexual relations. A psychiatrist, Dr Y, a clinical psychologist, Dr S and a social worker, BC, each gave written and oral evidence, making it an interesting case study. As part of the CoP proceedings, BC made three witness statements and was orally cross-examined. BC concluded that LC lacked the capacity to consent to sex and to marry. The local authority instructed $\operatorname{Dr} S$ to provide a further assessment of LC. Dr S initially concluded that LC lacked capacity to marry but may have capacity to consent to sex. However, in light of seeing Dr Y's report, she concluded that LC lacked the capacity to consent to sex. $\operatorname{Dr} Y$ was appointed as the independent expert following the commencement of CoP proceedings. Dr Y provided three written reports to the court as well as oral evidence. Dr Y concluded that LC lacked capacity in relation to both sex and marriage at all stages.

The psychiatrist's opinion was clearly given the most weight by the judge. In considering how much weight to attach to the evidence he stated in his judgment: 
The opinion of independently instructed experts is likely to be of considerable importance, but the court must look at all of the evidence...

That has particular relevance in the present case, where the experts initially applied tests of capacity which were incorrect; and in which I have been asked by the OS to concentrate upon their evidence in Court on [LC]'s understanding of particular issues.

What he meant was that in Dr Y's written report she had applied too high a threshold of understanding for capacity to consent to sex. $\operatorname{Dr} Y$ initially explained that LC would need to understand the psychological or emotional aspects of pregnancy and the risks of pregnancy, neither of which are parts of the test for capacity to consent to sex. ${ }^{57}$ Therefore even though the judge acknowledged that the experts used the incorrect legal tests, he still applied weight to their evidence, particularly the psychiatric evidence. For example, he phrased his analysis in terms that relegated the non-psychiatric evidence to secondary status by emphasising the psychiatric evidence and referring to the other evidence in brackets, writing 'In oral evidence, the view of $\operatorname{Dr}[\mathrm{Y}]$ (and of $\operatorname{Dr}[\mathrm{S}]$ and $\mathrm{Ms}[\mathrm{BC}]$ )' and then he only quoted only from $\mathrm{Dr} Y$ 's (psychiatric) report and not the others. This was despite that fact that LC had met with BC on around 15 occasions, with $\operatorname{Dr} S$ for around four hours over three sessions and with $\operatorname{Dr} Y$ on only one occasion for two and a half hours. Therefore the extent of contact with $\mathrm{P}$ had an inverse correlation with the authority attributed to the capacity opinion. These data reinforce the perception that deference to medical experts remains entrenched. Despite judicial rhetoric in reported judgments trying to address this issue, psychiatric evidence remains dominant in mental capacity law.

57 In Re A (Capacity: Refusal of Contraception) [2010] EWHC 1549. Therefore this is also a misunderstanding of the test for capacity to marry as that test incorporates a requirement that a person has capacity to consent to sex. 


\section{THE HIERARCHY ANALYSED: OBJECTIVE EXPERTISE VERSUS SUBJECTIVE EXPERIENTIAL KNOWLEDGE}

In this section I argue that the hierarchy outlined above remains entrenched in mental capacity law because of the way that psychiatric and social work evidence is viewed by professionals in the CoP. By this I mean that because psychiatric evidence is presented and analysed by judges and lawyers as objective, technical medical expertise, it is deferred to over the evidence of others. In contrast, because social work evidence is viewed to be more subjective and experiential, it has a lower status. I question this distinction as normatively accurate and instead argue that psychiatric evidence about capacity is also highly subjective. Illuminating this should assist in challenging the dominance of psychiatric evidence.

\section{Objective versus subjective knowledge claims}

As discussed at the start, one of the central reasons psychiatric evidence is viewed as objective, technical expertise about capacity is because of section 2 MCA. Evidence under this diagnostic threshold could fall within the domain of psychiatric expertise if it is accepted that a diagnosis is required to establish an impairment or disturbance in the functioning of the mind or brain. Psychiatry is the branch of medicine that deals with diagnosis and treatment of mental disorder. Therefore if a diagnosis of mental disorder is required under section 2 MCA then psychiatry, being the branch of medicine concerned with mental disorder, is likely to be the authority sought. ${ }^{58}$ If law is deferential to medicine even beyond the realm of its expertise through Bolamisation, then it is unsurprising that psychiatric professionals are still appointed

\footnotetext{
58 In the UK to become a fully qualified psychiatrist can take up to 13 years, a period which includes completing a medical degree, foundation training and then specialist training in the different branches of psychiatry, see Royal College of Psychiatrists $<$ https://www.rcpsych.ac.uk/discoverpsychiatry/acareerinpsychiatry.aspx> accessed 14 June 2018.
} 
as experts if a diagnosis is deemed required under section 2 MCA. Yet Ruck Keene et al. explain: 59

It is not necessary for the impairment or disturbance to fit into one of the diagnoses in the ICD-10 or DSM-V... therefore, the term "diagnostic" test is misleading - the important thing is that there is a proper basis upon which to consider that there is an impairment or disturbance.

This argument is based on the wording of section 2 MCA, which states that a person lacks capacity only if they are unable to make a decision 'because of an impairment of, or a disturbance in the functioning of, the mind or brain'. ${ }^{60}$ Their argument is that there is no specific legal requirement to have a diagnosed psychiatric disorder therefore the framing of the test under section 2 MCA as 'diagnostic' is misleading. This seems to be confirmed by the MCA Code of Practice which makes clear that '[t]emporary factors may also affect someone's ability to make decisions'. ${ }^{61}$ Whilst I agree with Ruck Keene et al.'s analysis, the language of the MCA arguably encourages the use of psychiatric evidence about capacity, even if it does not mandate it. This is because, in practice, assessment under what appears to be very similar to a diagnostic test is routinely interpreted as a clinical question. This can be seen in the way that research about capacity has developed into analysis of the effectiveness of cognitive tests and other seemingly objective measurements of capacity ${ }^{62}$ and that evidence in the CoP is most likely to be provided by a psychiatrist. ${ }^{63}$ Therefore unless section 2 MCA is amended or

59 A Ruck Keene, V Butler-Cole, N Allen, A Bicarregui, N Kohn and S Akhtar, Mental Capacity Law Guidance Note: Capacity Assessments (2016), 10.

60 MCA s 2.

61 Department for Constitutional Affairs, The Mental Capacity Act 2005: Code of Practice (The Stationery Office 2007) para 4.26.

62 NF Banner, (2012) 'Unreasonable reasons: normative judgements in the assessment of mental capacity', 18 Journal of Evaluation in Clinical Practice 1038-1044 and see TM Breden and J Vollmann, (2004) The cognitive based approach of capacity assessment in psychiatry: a philosophical critique of the MacCAT-T, 12 Health Care Analysis 273.

${ }^{63}$ See Case (n2), and Ruck Keene et al. (n59), 10. Also, see cases where the treating psychiatrist's evidence (rather than an independent expert) was seen as sufficient to make a capacity determination, for example Re QQ [2016] EWCOP 22, AN NHS Trust v A [2015] EWCOP 71 and Cambridge University Hospitals NHS Foundation Trust $v$ BF [2016] EWCOP 26. 
interpreted differently, psychiatric expertise about mental capacity is likely to continue to be adduced.

Whilst it is predominantly in the realm of the functional test that challenges to the medical domain have emerged, ${ }^{64}$ psychiatric evidence is still in some instances treated as objective expertise. For example, Case analysed the role of psychiatrists in evaluating the functional test for capacity and argues that it is 'fairly common for expert witnesses to make reference to P's 'lack of insight". ${ }^{65}$ Case shows that psychiatric experts focus on factors such as insight, even though they extend beyond the legislative requirements. This is important because insight is not a requirement for mental capacity under the MCA but it is still used by judges and considered as a legitimate technical point of analysis. Whilst 'insight' is not the focus of this article ${ }^{66}$ it highlights that psychiatrists are able to shape the meaning of expertise and extend their knowledge claim to non-relevant issues such as insight.

Social work evidence by contrast is more explicitly seen as experiential and subjective. Undertaking a social work qualification includes learning about 'legislation... social work theory, research, ethics and values. There is a big emphasis on practical learning... Social workers need skills in problem-solving, communication, working with others and patience'. ${ }^{67}$ Many of these skills are not technical but are based on a holistic understanding of human life. That is not to deny that social work is informed by evidence based practice; social workers do draw on evidence about what interventions or strategies work in what contexts, notwithstanding how some have questioned the usefulness of evidence based practice for social work. ${ }^{68}$ However, social work often involves dealing with multiple, layered and long-

\footnotetext{
$64 \mathrm{P}$ Case (n2), 181.

65 P Case, 'Dangerous Liaisons? Psychiatry and Law in the Court of Protection - Expert Discourses of 'Insight' (and 'Compliance')' 24 Medical Law Review 360, 364.

${ }^{66}$ Although it was used in at least two of the cases that were included as part of the CoP sample, for example in Y County Council v (1) LC (2) GK (3) SC the word 'insight' was mentioned at least 15 times at the final hearing. The term was also used in the case file in $H$ County Council $v$ XC.

67 British Association of Social Work <https://www.basw.co.uk/resources/become-social-worker> accessed 14 June 2018.

${ }^{68}$ AC Petersen and JI Olsson, (2015) 'Calling evidence-based practice into question: acknowledging phronetic knowledge in social work' 45 British Journal of Social Work 1581.
} 
standing different social (and other) issues in a person's life, rather than one single issue. ${ }^{69}$ This is important because, in contrast, a doctor typically specialises in an area and is therefore dealing with a single problem to a much greater extent than social workers. ${ }^{70} \mathrm{~A}$ social worker may be able to point to different evidence bases for different 'problems' in a person's life, but solutions to those problems might conflict in ways that are less obvious for psychiatrists, which in turn impacts on the knowledge claim that can be put forward.

This can be seen in reported case law where social work evidence has been adduced. For example, in London Borough of Redbridge v G \& Ors, an independent social work report was obtained but its focus was the 'wishes and feelings of $\mathrm{G}$ '. ${ }^{71}$ Furthermore, Russell $\mathrm{J}$ explicitly stated: $7^{72}$

[the social worker] is not qualified, as Dr Barker [the psychiatrist] is, to reach decisions as to mental impairment or disturbance. As a social worker... he does not have the knowledge and training that a psychiatrist possesses... his field is in welfare and as such he is well placed to give an opinion on the relationships and inter-personal functioning within G's household... he did not apply the tests in ss 2 and 3 of the MCA in his report nor was he asked to do so...

He then went on to explain that he preferred the evidence of the psychiatrist, 'given his speciality, expertise and knowledge of the functioning of the mind and brain. ${ }^{.73}$ This is a clear reflection of the contrasting ways that psychiatric and social work evidence are viewed by the CoP, with social work being seen as non-expert in respect of the test for mental capacity. Whereas psychiatrists have developed an exclusive claim to possessing expert technical

$69 \mathrm{P}$ Trevithick, (2008) 'Revisiting the Knowledge Base of Social Work: A Framework for Practice' 38 The British Journal of Social Work 1212, 1215.

70 Whilst this is not the case for all doctors such as General Practitioners (GPs) who cover a broader range of health problems, although even GPs can become accredited with a specialist interest.

${ }^{71}$ [2014] EWCOP 485, para 57

72 Para 61

73 Para 62 
knowledge about the diagnosis of mental disorder, ${ }^{74}$ social work has 'difficulty articulating and demarcating an exclusive knowledge base'. ${ }^{75}$ Social workers struggle to make knowledge claims about mental capacity based on objective, technical reasoning, making it more difficult for them to frame their knowledge as a claim of expertise in their own right. Instead, the knowledge claim of social workers is viewed as experiential; it is based on their experience of working with service users through their understanding of the environmental, interpersonal, economic and social factors at play in their service users' lives.

This distinction between psychiatric (objective, technical) knowledge and social work (subjective, experiential) knowledge was clear across the data. For example, all of my interviewees explicitly talked about their own judgement in specific cases. However, they were not able to point to a specific technical basis for their decisions, instead consistently referring to their experience. In doing this, and in referring to matters such as perception and judgement rather than diagnosis and treatment, the social workers presented their own knowledge using subjective discourse. For example, James talked about how he would decide whether or not a particular decision was a good one:

... partly discussing with other professionals, with the individual if they can... I know that's not a, I mean I don't know if there is now but there certainly wasn't when I was there a particular framework to decide what the outcome was, it was much more subjective. [James]. ${ }^{76}$

David also felt that he did not always have the time to make judgements or make them with the same confidence that he thought a judge would be able to:

\footnotetext{
${ }^{74}$ For example consider the use of the DSM, which has come to dominate understandings of mental disorder, see K Romelli, A Frigerio, A and M Colombo, (2016) 'DSM over time: From legitimisation of authority to hegemony' 11 BioSocieties 1.

${ }^{75} \mathrm{P}$ Trevithick (n69), 1213.

${ }^{76}$ James had in the region of 20 years' experience working as a social worker with adults with learning disabilities, followed by various practice management roles. At the time of the interview, James was no longer a practising social worker but was working in an adult social care research.
} 
I think again because the actual the applied sense of the law feels different to how a judge might unpick it... in that, for example, a judge could sort of have confidence in establishing... what is an appropriate timeframe or... a judge could sort of feel or give the impression of feeling confident about something. [David].

It became clear that social workers viewed themselves, and were viewed by law, as having a large degree of subjectivity in their decisions. This construction of subjectivity contributes to social workers' knowledge being valued less than that of psychiatrists. Social workers' relative lack of knowledge about law, the courtroom and evidence giving may also contribute to their perceived subjectivity. For example, Robert said 'it's scary and inaccessible the law, you know'. ${ }^{77}$ David explained his experience with the court process: 'I had to write the court report and that was a really chastening experience for me'. Julia said 'I get a little bit confused when it comes to the Court of Protection part of things so the higher level stuff and what you would take there and what you wouldn't. ${ }^{78}$ Sarah told me about a case that she was in the initial stages of bringing to the CoP, she said 'I'm worried that, I don't want to feel underprepared or that they're gonna ask us a question that we just don't know, or that we're gonna look silly in some way. ${ }^{179}$ Perhaps it is unsurprising that if social workers found the process of giving evidence in CoP proceedings challenging, this further weakened their evidential claims. In contrast to social work deference to medicine persists and this extends to decisions about mental capacity, particularly where expertise can be claimed in relation to the traditional domain of medical skill - diagnosis. As social workers lack this technical claim it is perhaps

\footnotetext{
77 Robert was a qualified social worker with a number of years' experience in frontline and managerial roles. He was a manager of a learning disability team in a local authority during the period in which the MCA came into force. At the time of interview he was in a practice development social work role.

78 Julia had a number of years' experience as a local authority social worker. Her role at the time of interview was as a social worker in a secure unit with inpatient and outpatient adults who had mental health difficulties.

79 Sarah was a qualified social worker and at the time of interview had been working in an adult safeguarding enquiry team for four years.
} 
unsurprising that they struggle to have their evidence valued on an equal basis, even though the value in both should derive from their professional relationship with $\mathrm{P}$.

The contrast between the characterisation of social work and psychiatric evidence was also clear in the LC case. For example, in his judgment the judge explained:

I do accept that there is almost inevitably some element of subjectivity in the approach taken by social workers who are trying to protect the welfare of a vulnerable adult, and that is so in the present case - where the concern of the local authority was concentrated upon the marriage and the relationship between [LC] and [GK] (the specifics of which are not relevant to the general questions this court must answer). Nevertheless, on factual issues and when assessing [LC]'s ability to understand and process information and deal with issues, I considered [social worker's] evidence to be fair and balanced.

Yet the social worker, BC, gave detailed evidence about LC and provided the clearest sense of her character. My observational notes state:

SW [social work] evidence was persuasive, felt like she had a much better grasp of LC's character and was able to draw on her meetings in a way that seemed much more genuine than the experts... Yet SW evidence seemingly less important, submitted to judge that they are experts on issues of contact, care and residence by OS [official solicitor], but clearly judge did not find persuasive from his comments in his case management judgment. [Observational field notes].

BC's oral evidence did not include any discussion of the diagnostic test for capacity, other than minimal references to LC's IQ and learning disability. This reinforces the perception that social work evidence is not deemed relevant to the diagnostic aspect of the capacity test due 
to their lack of technical expertise in diagnosing mental disorder. The majority of BC's evidence focused on LC's understanding of the information relevant to decisions about sex and marriage. For example, BC explained that LC understood the mechanics of sexual activity and had experience of sexual encounters, but believed that sex was meant to hurt and, in relation to sexually transmitted infections, that if everything looked normal there were no health risks. BC gave extensive evidence on matters relating to the functional aspect of capacity and provided an extremely colourful and detailed insight into LC's character. My observational notes record that BC was an 'impressive witness, clearly has strong relationship with LC, much more specific than the psychiatrists before her'. However, her evidence was framed subjectively. Questions were focused around what BC asked LC and what BC thought LC's understanding was of the matters discussed.

In contrast, the attempted use of technical, objective language by $\operatorname{Dr} \mathrm{Y}$ (psychiatrist) and to some extent $\operatorname{Dr} S$ (clinical psychologist) was evident. For example, in relation to the diagnostic threshold questioning focused on technical issues such as 'scientific' testing of LC's abilities. Dr S explained that she carried out what is commonly known as an IQ test based on the Wechsler Adult Intelligence Scale (WAIS) test, and that LC had an IQ of 57, which represents the lowest 2 percentile of the population. Similarly, $\operatorname{Dr} Y$ explained that LC had a mild learning disability which meant that LC was in the 'extremely low range'. This evidence was presented, particularly by $\operatorname{Dr} \mathrm{Y}$, in objective language; she was able to go through the tests carried out in detail, seemingly to convince the court that the approach was rigorous and scientific and part of her medical expertise.

\section{Challenging the dominance of psychiatric knowledge}

On a deeper analysis of psychiatric knowledge, their evidence about mental capacity cannot always be framed as objective expertise. First, there are legitimate challenges to the expertise of psychiatry in the realm of diagnosis of mental disorder, which impacts on the validity of the technical claim to objectivity that can be made. For example, '[c]ompeting schools within the 
psy-complex hold divergent beliefs regarding the existence of specific conditions' ${ }^{80}$ There are debates over the legitimacy of psychiatry's claim to have a biomedical foundation. Romelli et al. undertook an analysis of the discursive strategies used in the Diagnostic and Statistical Manual of Mental Disorders (DSM), one of the leading manuals used by psychiatry, published by the American Psychiatric Association (APA) ${ }^{81}$ They argue that the use of empiricist and biomedical language in relation to the classification of mental disorder, which is often referred to as 'the empiricist repertoire', ${ }^{82}$ has contributed to the legitimation of medical and psychological discourse. In claiming that the diagnosis of mental disorder is empirically based, these professions imply 'the existence of a knowledge base about mental disorders that is valid, regardless of beliefs in etiology or treatment'. ${ }^{83}$ However, this medicalised, objective, language obscures the hidden value judgements and the often-present disagreements and uncertainties that lay behind the classification of mental disorder. The Chair of the British Psychological Society similarly highlights difficulties with the DSM/psychiatric approach including the challenges in agreeing definitions of mental disorder, the limits of neuroscience and the problems in elucidating an epistemology of mental disorder ${ }^{84}$

Second, psychiatric knowledge can be challenged when analysing the functional test. Whether or not a person is able to understand, retain, use or weigh information, or communicate their decision, are not matters that fall within the medical skill of diagnosis and treatment. This is because how a person understands, retains or uses information varies depending on the person, it is not an abstract technical matter of how people with that particular diagnosis make decisions. Psychiatrists may still have useful experiential knowledge to contribute if they have relevant professional experience. However, their knowledge about

\footnotetext{
80 See K Romelli (n74), 1.

81 lbid.

82 K Burchell, (2007) 'Empiricist selves and contingent "others": the performative function of the discourse of scientists working in conditions of controversy' 16 Public Understanding of Science 145, $\mathrm{K}$ Romelli, A Frigerio and M Colombo, 'DSM over time: From legitimisation of authority to hegemony'. ${ }^{83} \mathrm{JA}$ Cermele, S Daniels and KL Anderson, (2001) 'Defining Normal: Constructions of Race and Gender in the DSM-IV Casebook' 11 Feminism \& Psychology 229, 229.

${ }^{84}$ A Frances, (2010) 'The first draft of DSM-V' 340 BMJ 492 A Frances and T Widiger, (2012) 'Psychiatric diagnosis: lessons from the DSM-IV past and cautions for the DSM-5 future' 8 Annual Review of Clinical Psychology 109.
} 
this is also experiential and similar to that of other professionals, rather than having preeminent status.

This can be seen in Dr Y's evidence when she was asked about LC's ability to weigh up information about contact with GK under the functional test. She said 'I think that's quite difficult to assess as when he's not in contact with her she's able to talk things through with people who have her best interests at heart but as soon as he's back in contact with her he's a persuasive character'. This analysis lacks any substantive psychiatric expertise and is surely something that anybody who knew LC would have been able to observe. This resonates with much of the language throughout proceedings about LC's acquiescence, again not a legally relevant factor. Counsel for the Official Solicitor explained 'The psychiatric and social work evidence does go to [LC]'s capacity to weigh matters because of suggestibility, comply and acquiesce, and inability to understand motives'. Counsel repeatedly tried to bring the evidence back to the legal test by using the language of weighing and retaining because the experts were not doing this. My observational notes record that $\operatorname{Dr} Y$ did not mention the words weigh or retain once in her oral evidence. Dr S only mentioned weigh three times and did not mention the word retain at all.

In relation to LC's understanding under the functional test, $\operatorname{Dr} Y$ explained that she 'understands by having sex you can get pregnant, when asked about how many times she said she thought you'd have to be having sex every day to get pregnant'. She further explained that in LC's mind, you have sex and then you have a baby, 'I don't think she has any idea what happens in between. She knows you have to have a midwife, but she doesn't know what the midwife is for, what tests you might have to have etc.' In relation to LC's understanding of marriage Dr Y explained that LC did not understand the social aspects. She said 'she has a slightly old fashioned concept' and this was because she believed that [GK] would go to work and buy the house and that she would stay at home and do the cooking. $\operatorname{Dr} Y$ went on to explain that LC thought that once married she wouldn't be allowed to speak to other men. Again, none of these factors were part of the information relevant to the decisions in question, nor did they relate to Dr Y's technical expertise. 
Pre and post-MCA studies have also found a failure to use the functional approach to assess capacity. ${ }^{85}$ Nine years after the coming into force of the MCA some psychiatrists appear not to use the language of the functional approach, instead determining capacity in relation to subjective social factors such as understanding of 'normal' social expectations and by making comparisons with children. Yet in allowing a psychiatrist to discuss social factors, those factors are effectively 'redefined using clinical euphemisms... to remove or neutralise the moral character of the issues at stake'. ${ }^{86}$ Psychiatrists import highly subjective social and moral factors into their discussions but do so using technical and clinical language. Dr Y's comments about the functional approach were in fact comments on normative moral matters that had little to do with Dr Y's 'objective' psychiatric expertise. Despite that, the judge placed greatest weight on the psychiatric evidence, relying on it as the primary source to support his finding that LC lacked capacity to consent sex and capacity to marry.

The evidence suggests that psychiatric evidence is repeatedly and uncritically accepted as objective expertise about mental capacity, allowing it to dominate CoP proceedings. If the intention in creating the MCA had been to import a technical psychiatric approach to understanding capacity then one would expect the legislative and psychiatric language to align, but it does not. On a deeper analysis, there is a large degree of subjectivity in the psychiatric evidence in the CoP, which is in many instances comparable to the subjectivity of the social work evidence. This is not a criticism of psychiatric evidence. I have highlighted how the medical knowledge of psychiatrists is deferred to by the CoP, even over the evidence of other professionals with greater experiential knowledge of $P$.

\section{VALUING EXPERIENTIAL KNOWLEDGE IN DETERMINING MENTAL CAPACITY}

\footnotetext{
85 WMI Suto, ICH Clare and AJ Holland, (2002) 'Substitute financial decision-making in England and Wales: a study of the Court of Protection' 24 Journal of Social Welfare and Family Law 37, 48, C Emmett, M Poole, J Bond, J and JC Hughes, (2013) 'Homeward bound or bound for a home? Assessing the capacity of dementia patients to make decisions about hospital discharge: Comparing practice with legal standards' 36 International Journal of Law and Psychiatry 73.

${ }^{86} \mathrm{P}$ Case (n65), 375.
} 
The discourse of subjectivity around social work has the effect of delegitimising their knowledge claims. However, as outlined above, psychiatric knowledge about mental capacity can also be subjected to a critique of subjectivity. In light of legitimate concerns about psychiatric knowledge being given greater weight, I argue for a more relational approach to capacity assessments, with greater value being placed on experiential evidence about mental capacity. This includes the professional experiential knowledge of those who work closely with $\mathrm{P}$ as well as the personal experiential knowledge of $\mathrm{P}$ herself. ${ }^{87} \mathrm{~A}$ relational approach to assessing capacity involves removing the need for an expert capacity assessor who is an 'objective outsider' and instead focuses on understanding P's situated position. ${ }^{88}$

\section{Capacity Assessments as a Relational Interaction}

A relational approach to assessing capacity would foremost involve recognising that a capacity assessment is the product of a relational interaction. As Donnelly states, 'Regardless of who carries out an assessment of capacity, at a fundamental level, the assessment must be recognised as a personal encounter between two people'. ${ }^{89}$ Therefore a relational approach accepts that where that encounter is based on a positive relationship, it is likely to be more facilitative of P's autonomy. In this sense a relational approach to capacity assessment recognises the benefits of relationships to facilitating capacity. ${ }^{90}$ Relationality acknowledges that choices cannot be properly understood without seeing them in context - without taking account of the multi-dimensional social, economic, political and geographical features of the person's life. This is in contrast to understanding the world as composed of atomistic, rational actors.

\footnotetext{
$87 \mathrm{~J}$ Lindsey (n7).

$88 \mathrm{M}$ Donnelly, Healthcare Decision-Making and the Law: Autonomy, Capacity and the Limits of Liberalism (Cambridge University Press 2010), 113.

89 M Donnelly (n15), 477.

90 See C Mackenzie and N Stoljar (eds), Relational Autonomy: Feminist Perspectives on Autonomy, Agency, and the Social Self (Oxford University Press 2000), Nedelsky, J, Law's Relations: A relational theory of self, autonomy, and law (Oxford University Press 2011).
} 
Relational theory also recognises the harm that relationships can create. ${ }^{91}$ Exploitative relationships might be less common in the professional context, ${ }^{92}$ but a poor or non-existent relationship with an assessor can undermine P's understanding. For example, if an independent psychiatrist was appointed to assess P's capacity based on a single meeting of no more than a couple of hours, as in most cases I observed, the lack of a developed relationship between the two could be a major factor underpinning a finding of incapacity. This is firstly because of the need to have information presented in an accessible format, ideally over more than one occasion..$^{93}$ Secondly, P may feel unable to express her 'true' feelings or may feel untrusting of a person in authority. That is why there has been such a focus in the literature on involving those around $P$ in the decision-making process. ${ }^{94}$ Therefore an independent professional assessing $\mathrm{P}$ over a matter of one or two hours is likely to have less reliable information on which to base their judgement about P's capacity than a professional with a well-established relationship with $\mathrm{P}$.

Having a capacity assessment carried out by a person who has experiential knowledge about $P$ is also more likely to get to the truth of $P$ 's understanding. This is for all of the reasons identified above. That where $\mathrm{P}$ does not understand or attempts to resist the professional's line of communication they are less likely to gain accurate information about P's understanding. Experiential knowledge is strengthened by having direct experience of how $\mathrm{P}$ functions and by having a good relationship with $P$ from which accurate information can be obtained. ${ }^{95}$ The need for a relational approach is also important because of the need to

\footnotetext{
${ }^{91}$ C Mackenzie and N Stoljar, Relational Autonomy: Feminist Perspectives on Autonomy, Agency, and the Social Self.

${ }^{92}$ By this I mean that legal proceedings should identify allegations of abuse by the professionals working with $\mathrm{P}$ and therefore abuse by the psychiatrist or social worker is probably less common, albeit there are cases of abuse by professionals and abuse by family members should similarly not be underestimated, for further discussion see A Hollomotz, Learning difficulties and sexual vulnerability: a social approach (Jessica Kingsley Publishers 2011) and SB Plummer and PA Findley, (2012) 'Women With Disabilities' Experience With Physical and Sexual Abuse: Review of the Literature and Implications for the Field' 13 Trauma, Violence, \& Abuse 15.

${ }_{93}$ M Donnelly (n88), 112.

${ }^{94}$ A Arstein-Kerslake and E Flynn, (2016) 'Legislating Consent: Creating an Empowering Definition of Consent to Sex That Is Inclusive of People With Cognitive Disabilities' 25 Social \& Legal Studies 225.

${ }^{95}$ This can also be seen in cases where $\mathrm{P}$ has not been willing to engage with capacity assessors. For example, in Manchester City Council Legal Services v LC \& Anor [2018] EWCOP 30 P was unwilling to discuss her understanding of sex with a male assessor.
} 
understand the consequences of a decision of (in)capacity. Those who are familiar with the person are therefore likely to have a valuable contribution to make. ${ }^{96}$ They may better understand what assistance $P$ needs to be able to understand and retain information, how she comes to her decisions, what factors she values and what support might be needed to facilitate her capacity. Technical experts on particular disorders may also have a role to play in capacity assessments. However, these insights must be coupled with experiential knowledge of how the individual $P$ thinks and makes decisions.

The reality of capacity assessments is that 'the issue of P's capacity will often comprise a value judgement, informed by the decision-maker's perspective on where the line between autonomy and best interests decisions should be drawn'. ${ }^{97}$ This is because the subject matter of the case, and therefore the outcome, ${ }^{98}$ is likely to influence the capacity judgement that is made. When cases involve allegations of abuse it is not surprising that such judgments fall on the side of incapacity because of the imperative to protect. However, by failing to prioritise the opinions of those who know $\mathrm{P}$ best, it is easier for the CoP to ignore the implications of findings of incapacity. A central way of challenging this is by limiting the value attributed to the knowledge claims of those who do not have a relationship with P. Instead, by viewing capacity in relational terms, the evidence of those professionals (typically social workers) and P's family and friends is likely to be given greater value.

96 HM Chan, (2004) 'Sharing Death and Dying: Advance Directives, Autonomy and the Family' 18 Bioethics 87, J Herring, Caring and the Law (Hart 2013).

97 P Case (n65), 376.

$98 \mathrm{M}$ Donnelly (n88), 114. 


\section{The Case for Independence?}

One critique of a relational approach is that there is value in an independent assessment for court proceedings. Those closest to P may have strong views about what they think is best, may seek to persuade $\mathrm{P}$ of a particular outcome or may be acting for personal gain. Therefore in some cases independence is necessary to avoid bias, both real and perceived. More often than not, independence was raised by the family or $\mathrm{P}$ rather than any other party. ${ }^{99}$ It is understandable that those subject to mental capacity proceedings may not feel comfortable with the evidence of their social worker being used for a finding of incapacity. This is because in most cases social workers will have brought the matter to the CoP and therefore may be perceived to have already 'made up their mind'. This perception of bias, whether real or otherwise, should be addressed. However, appointing an independent psychiatric expert raises a number of other concerns as identified throughout and does not provide a solution to this challenge. In fact, as Case states: ${ }^{100}$

...it is perhaps the non-treating expert who should give more cause for concern here. These experts are more likely to give repeat performances in CoP proceedings and, therefore, any personal or professional perspective they have on capacity... will likely have a bigger impact on mental capacity hearings generally.

Instead, it must be addressed through the judge emphasising to the parties that they are an independent arbiter of the evidence. If the judge identifies bias in the evidence then it may be necessary to appoint an independent expert ${ }^{101}$ to assess $P$. Importantly though, my suggestion

\footnotetext{
${ }^{99}$ For example, this occurred in $H$ County Council $v X C$ and was a clear undertone of the cases where $P$ challenged their deprivation of liberty under MCA s $21 \mathrm{~A}$ including YS $v E$ District Council, OD v R City Council and T City Council $v \mathrm{CY}$.

100 P Case (n2), 200.

101 This could be a social worker, psychiatrist or another professional who is regularly involved in P's life. Social workers were the professionals that most often brought the CoP proceedings. However, a
} 
focuses on the need for a regular period of work with and review of P's situation from a holistic perspective rather than a one-off medical assessment. The purpose of this extended interaction would be to enable the independent appointee to understand P's capacity more comprehensively than a one-off assessment allows.

Some may raise resource concerns about engaging professionals to work with $\mathrm{P}$ on a longer-term basis. However, this would only happen in cases where there were concerns about a lack of independence or bias. Second, the cost of instructing independent psychiatric experts routinely in every case is high. Whilst section 49 MCA reports can be ordered, which require an NHS Trust to provide a report at no cost to the parties, ${ }^{102}$ this does not always occur. ${ }^{103}$ Furthermore, given that section 49 also makes provision for a local authority employee to provide a report, there is no legal reason why a social worker from another local authority for example could not be instructed. This would involve limited additional resource burden and may actually be cheaper given the respective costs of a psychiatrist and social worker's salary. However, rebalancing the evidence in mental capacity cases so that it is based on experiential knowledge about $\mathrm{P}$ is essential. It broadens the range of evidence available to the court, is more likely to provide accurate information about $\mathrm{P}$ and it values the experiences of $\mathrm{P}$ and those around her. In those cases where there is a concern about independence then alternative measures can be taken which do not involve privileging expert knowledge claims.

\section{CONCLUSION}

In this article I have highlighted the different categories of professional knowledge within mental capacity law, outlining a hierarchy of professional evidence. Psychiatric knowledge

speech and language therapist might be appropriate, or if P's main contact was with a learning disability nurse then they may be the best professional etc.

102 As affirmed in RS v (1) LCC (2) $A B$ and (3) AL [2015] EWCOP 56.

${ }^{103}$ For further detail about the use of section 49 reports in the CoP see L Series, P Fennell, J Doughty and A Mercer, Welfare cases in the Court of Protection: A statistical overview (Cardiff 2017). 
remains at the top of this hierarchy, despite there being no legal requirement for medical evidence on mental capacity. This hierarchy exists because of law's continued deference to the medical profession and this translates into psychiatric evidence on capacity being understood as objective, technical expertise. I have challenged this characterisation and emphasised the value in experiential evidence. Social workers tend to have an ongoing and developed personal relationship with $\mathrm{P}$ when contrasted with an expert who may only meet $\mathrm{P}$ on one occasion for the purposes of a capacity assessment, thereby giving social workers a strong experiential knowledge claim, particularly within the capacity domains that I explored. Medical knowledge might be useful in identifying particular weaknesses in decision-making processes attributable to specific disorders, but mental capacity is not a technical concept that always requires specialist expertise to untangle.

In thinking through ways that mental capacity law might start to address this hierarchy, I have suggested that capacity assessments in CoP proceedings should routinely be carried out by a person with whom $\mathrm{P}$ has an established relationship. This may be a psychiatrist if that is the professional with whom $\mathrm{P}$ has an established relationship, but the CoP should be more open to a wider range of experts, including non-medical professionals. Further research is needed to understand the ways that $P$ can be supported to achieve capacity and to communicate effectively with capacity assessors. Whilst research has been carried out into supported decision-making, ${ }^{104}$ capacity assessments are still being carried out regularly for CoP cases by independent outsiders who have very limited knowledge of P's individual circumstances. There is an immediate need to consider ways that evidence on capacity can better reflect P's knowledge, experiences and capabilities so that decisions about mental capacity are based on the most reliable knowledge available.

\footnotetext{
${ }^{104}$ For example see R Harding and E Tascioglu, 'Everyday decisions project report: supporting legal capacity through care, support and empowerment' (November 2017) $<$ http://epapers.bham.ac.uk/3067/1/Everyday Decisions Project Report.pdf > accessed 14 June 2018.
} 
Acknowledgments: The author would like to thank Mary Donnelly, Sabine Michalowski, Rosie Harding and Marie Fox for their feedback on earlier drafts, as well as the two anonymous reviewers for their comments. 
Table one: Expert evidence in Court of Protection case files reviewed

\begin{tabular}{|c|c|c|c|c|c|c|c|c|c|}
\hline & Case name & Sex & Age & Disability & $\begin{array}{l}\text { Keyword } \\
\text { summary }\end{array}$ & $\begin{array}{l}\text { Expert } \\
\text { evidence } \\
\text { obtained }\end{array}$ & $\begin{array}{l}\text { Manner expert } \\
\text { evidence given }\end{array}$ & $\begin{array}{l}\text { Other } \\
\text { (professional) } \\
\text { evidence }\end{array}$ & Outcome \\
\hline 1. & $\begin{array}{l}\text { K County } \\
\text { Council v SL }\end{array}$ & $F$ & 20 & $\begin{array}{l}\text { Mild learning } \\
\text { disability }\end{array}$ & $\begin{array}{l}\text { Forced } \\
\text { marriage }\end{array}$ & Psychiatry & Written report & $\begin{array}{l}\text { Social work (by } \\
\text { way of statement } \\
\text { in CoP } \\
\text { application) } \\
\text { General } \\
\text { practitioner }\end{array}$ & $\begin{array}{l}\text { Has capacity. } \\
\text { Proceedings } \\
\text { withdrawn. }\end{array}$ \\
\hline 2. & $\begin{array}{l}M L \vee(1) T L \\
\text { and (2) } D \\
\text { County } \\
\text { Council }\end{array}$ & $\mathrm{M}$ & 82 & Dementia & $\begin{array}{l}\text { Domestic } \\
\text { abuse }\end{array}$ & Unknown & Unknown & Unknown & $\begin{array}{l}\text { ML died before } \\
\text { final hearing. }\end{array}$ \\
\hline 3. & $\begin{array}{l}\text { Z County } \\
\text { Council v FY }\end{array}$ & $F$ & 66 & Dementia & $\begin{array}{l}\text { Domestic } \\
\text { abuse }\end{array}$ & Unknown & Unknown & Unknown & $\begin{array}{l}\text { Final order. FY } \\
\text { lacks capacity to: } \\
\text { conduct } \\
\text { proceedings, } \\
\text { decide on } \\
\text { residence, care } \\
\text { and contact. }\end{array}$ \\
\hline 4. & $\begin{array}{l}Y \text { County } \\
\text { Council V (1) } \\
L C(2) G K(3) \\
S C\end{array}$ & $\mathrm{~F}$ & 23 & $\begin{array}{l}\text { Autism and } \\
\text { mild learning } \\
\text { disability }\end{array}$ & $\begin{array}{l}\text { Domestic } \\
\text { abuse } \\
\text { Forced } \\
\text { Marriage }\end{array}$ & $\begin{array}{l}\text { Psychiatry } \\
\text { Clinical } \\
\text { psychology }\end{array}$ & $\begin{array}{l}\text { Written report } \\
\text { and oral } \\
\text { evidence from } \\
\text { two expert } \\
\text { witnesses }\end{array}$ & $\begin{array}{l}\text { Social work (by } \\
\text { way of statement } \\
\text { in CoP } \\
\text { application) }\end{array}$ & $\begin{array}{l}\text { Final order. LC } \\
\text { lacks capacity to: } \\
\text { consent to sex, } \\
\text { to marry and to } \\
\text { litigate. Case } \\
\text { ongoing in } \\
\text { relation to } \\
\text { contact and } \\
\text { residence. }\end{array}$ \\
\hline
\end{tabular}




\begin{tabular}{|c|c|c|c|c|c|c|c|c|c|}
\hline 5. & $\begin{array}{l}\text { W County } \\
\text { Council v ZR }\end{array}$ & $F$ & 37 & $\begin{array}{l}\text { Learning } \\
\text { disability }\end{array}$ & $\begin{array}{l}\text { Domestic } \\
\text { abuse }\end{array}$ & None & $\mathrm{N} / \mathrm{A}$ & $\begin{array}{l}\text { Learning } \\
\text { disabilities nurse } \\
\text { (by way of } \\
\text { statement in CoP } \\
\text { application) }\end{array}$ & $\begin{array}{l}\text { Proceedings } \\
\text { stayed as ZR } \\
\text { detained under } \\
\text { s3 Mental Health } \\
\text { Act } 1983 \text {. } \\
\end{array}$ \\
\hline 6. & $\begin{array}{l}\text { C Borough } \\
\text { Council v (1) } \\
\text { DY (2) B } \\
\text { Council }\end{array}$ & $F$ & 20 & $\begin{array}{l}\text { Learning } \\
\text { difficulties }\end{array}$ & $\begin{array}{l}\text { Disruptive } \\
\text { behaviour }\end{array}$ & $\begin{array}{l}\text { Reference to } \\
\text { both } \\
\text { independent } \\
\text { social work } \\
\text { report and } \\
\text { report of a } \\
\text { doctor }\end{array}$ & Unknown & Unknown & $\begin{array}{l}\text { Final order. DY } \\
\text { lacks capacity to: } \\
\text { conduct } \\
\text { proceedings, } \\
\text { make decisions } \\
\text { as to residence, } \\
\text { care and contact. }\end{array}$ \\
\hline 7. & $\begin{array}{l}\text { A County } \\
\text { Council v (1) } \\
M T \text { (2) KZ }\end{array}$ & $\mathrm{M}$ & 52 & $\begin{array}{l}\text { Mild to } \\
\text { moderate } \\
\text { learning } \\
\text { disability }\end{array}$ & $\begin{array}{l}\text { Forced } \\
\text { Marriage }\end{array}$ & Psychiatry & Written report & None & $\begin{array}{l}\text { Ongoing. Interim } \\
\text { decision that MT } \\
\text { lacks capacity to: } \\
\text { conduct } \\
\text { proceedings, } \\
\text { decide on } \\
\text { residence and } \\
\text { care, consent to } \\
\text { sexual relations } \\
\text { and marry. }\end{array}$ \\
\hline 8. & $\begin{array}{l}H \text { County } \\
\text { Council } v \text { XC }\end{array}$ & $\mathrm{M}$ & 24 & $\begin{array}{l}\text { Learning } \\
\text { disability and } \\
\text { deafness }\end{array}$ & $\begin{array}{l}\text { Forced } \\
\text { marriage }\end{array}$ & $\begin{array}{l}\text { Clinical } \\
\text { psychology }\end{array}$ & Written report & $\begin{array}{l}\text { Social work (by } \\
\text { way of statement } \\
\text { in CoP } \\
\text { application) } \\
\text { Sex and } \\
\text { relationships } \\
\text { counsellor (report } \\
\text { on educative } \\
\text { work) }\end{array}$ & $\begin{array}{l}\text { Ongoing. Interim } \\
\text { decision that XC } \\
\text { lacks capacity to: } \\
\text { consent to sexual } \\
\text { relations and } \\
\text { marry. }\end{array}$ \\
\hline 9. & $\begin{array}{l}\text { M County } \\
\text { Council V EV }\end{array}$ & $\mathrm{M}$ & 21 & $\begin{array}{l}\text { 'Mental health } \\
\text { problems' }\end{array}$ & $\begin{array}{l}\text { Forced } \\
\text { marriage }\end{array}$ & $\begin{array}{l}\text { Expert } \\
\text { appointed, }\end{array}$ & Unknown & Unknown & $\begin{array}{l}\text { Final order. EV } \\
\text { lacks capacity to: }\end{array}$ \\
\hline
\end{tabular}




\begin{tabular}{|c|c|c|c|c|c|c|c|c|c|}
\hline & & & & & & $\begin{array}{l}\text { discipline } \\
\text { unknown }\end{array}$ & & & $\begin{array}{l}\text { litigate, decide on } \\
\text { residence, care } \\
\text { and contact, and } \\
\text { manage his } \\
\text { finances. }\end{array}$ \\
\hline 10. & $\begin{array}{l}\text { T City } \\
\text { Council v CY }\end{array}$ & $F$ & 49 & $\begin{array}{l}\text { Mild to } \\
\text { moderate } \\
\text { learning } \\
\text { disability, } \\
\text { emotionally } \\
\text { unstable } \\
\text { personality } \\
\text { disorder }\end{array}$ & $\begin{array}{l}\text { Relationsh } \\
\text { ip with } \\
\text { partner }\end{array}$ & $\begin{array}{l}\text { Expert } \\
\text { appointed, } \\
\text { discipline } \\
\text { unknown }\end{array}$ & Written report & Unknown & $\begin{array}{l}\text { Final order. CY } \\
\text { lacks capacity to: } \\
\text { conduct } \\
\text { proceedings, } \\
\text { decide on } \\
\text { residence and } \\
\text { care. She does } \\
\text { have capacity to } \\
\text { decide on } \\
\text { contact. }\end{array}$ \\
\hline 11. & $\begin{array}{l}J \text { Council v } \\
R K\end{array}$ & $\mathrm{M}$ & 38 & $\begin{array}{l}\text { Down's } \\
\text { Syndrome } \\
\text { and learning } \\
\text { disability }\end{array}$ & $\begin{array}{l}\text { Alleged } \\
\text { abuse by } \\
\text { wife (on } \\
\text { basis of } \\
\text { lack of } \\
\text { capacity) }\end{array}$ & $\begin{array}{l}\text { Expert } \\
\text { appointed, } \\
\text { discipline } \\
\text { unknown }\end{array}$ & Unknown & Unknown & $\begin{array}{l}\text { Transferred to } \\
\text { High Court judge } \\
\text { for final hearing } \\
\text { as case concerns } \\
\text { consent to } \\
\text { medical } \\
\text { treatment. } \\
\text { Awaiting expert } \\
\text { evidence and } \\
\text { final resolution at } \\
\text { time of research } \\
\text { end. }\end{array}$ \\
\hline 12. & $\begin{array}{l}\text { K County } \\
\text { Council v } \\
\text { MW }\end{array}$ & $F$ & 20 & $\begin{array}{l}\text { Learning } \\
\text { disability }\end{array}$ & $\begin{array}{l}\text { Forced } \\
\text { marriage }\end{array}$ & $\begin{array}{l}\text { Clinical } \\
\text { psychology }\end{array}$ & Written report & $\begin{array}{l}\text { Social work (by } \\
\text { way of statement } \\
\text { in CoP } \\
\text { application) } \\
\text { Relationship and } \\
\text { sexual health } \\
\text { counsellor }\end{array}$ & $\begin{array}{l}\text { Ongoing. Interim } \\
\text { finding that MW } \\
\text { had capacity in } \\
\text { relation to sex } \\
\text { but lacked } \\
\text { capacity in } \\
\text { relation to } \\
\text { marriage. }\end{array}$ \\
\hline
\end{tabular}




\begin{tabular}{|c|c|c|c|c|c|c|c|c|c|}
\hline 13. & $\begin{array}{l}N \text { County } \\
\text { Council v (1) } \\
\text { Gl and (2) } \\
D Q\end{array}$ & $F$ & 62 & $\begin{array}{l}\text { Korsakoff's } \\
\text { syndrome, } \\
\text { personality } \\
\text { disorder, } \\
\text { depressive } \\
\text { disorder and } \\
\text { cerebral } \\
\text { atrophy }\end{array}$ & $\begin{array}{l}\text { Domestic } \\
\text { abuse }\end{array}$ & Unknown & Unknown & Unknown & $\begin{array}{l}\text { Ongoing. Interim } \\
\text { findings that GI } \\
\text { lacks capacity to: } \\
\text { litigate, decide on } \\
\text { contact, care and } \\
\text { residence. }\end{array}$ \\
\hline 14. & $\begin{array}{l}\text { N County } \\
\text { Council v CA }\end{array}$ & $M$ & 57 & $\begin{array}{l}\text { 'Low } \\
\text { intelligence' }\end{array}$ & $\begin{array}{l}\text { Sexual } \\
\text { offences }\end{array}$ & Unknown & Unknown & Unknown & $\begin{array}{l}\text { Ongoing. Interim } \\
\text { declaration that } \\
\text { CA: } \\
\text { lacks capacity to } \\
\text { conduct } \\
\text { proceedings; } \\
\text { but has capacity } \\
\text { to consent to } \\
\text { sexual relations. } \\
\text { Separate } \\
\text { proceedings } \\
\text { alongside } \\
\text { considering CA's } \\
\text { partner (NF)'s } \\
\text { capacity to make } \\
\text { decisions about } \\
\text { residence and } \\
\text { care, capacity to } \\
\text { marry in the } \\
\text { future, capacity } \\
\text { to consent to } \\
\text { sexual relations, } \\
\text { capacity to make } \\
\text { decisions about } \\
\text { contraception }\end{array}$ \\
\hline
\end{tabular}




\begin{tabular}{|c|c|c|c|c|c|c|c|c|c|}
\hline & & & & & & & & & $\begin{array}{l}\text { and capacity to } \\
\text { decide what } \\
\text { contact to have } \\
\text { with other } \\
\text { relevant } \\
\text { individuals. }\end{array}$ \\
\hline 15. & $\begin{array}{l}\text { YS v E } \\
\text { District } \\
\text { Council }\end{array}$ & $\mathrm{M}$ & 52 & $\begin{array}{l}\text { Heavy } \\
\text { alcohol } \\
\text { consumption } \\
\text { and brain } \\
\text { injury }\end{array}$ & $\begin{array}{l}\text { Sexual } \\
\text { offences }\end{array}$ & Unknown & Unknown & Unknown & $\begin{array}{l}\text { Ongoing. Interim } \\
\text { declaration that } \\
\text { YS lacks } \\
\text { capacity to: } \\
\text { conduct } \\
\text { proceedings, } \\
\text { decide on care } \\
\text { and residence. } \\
\text { At end of } \\
\text { research transfer } \\
\text { of placement was } \\
\text { due to take place } \\
\text { with further } \\
\text { review } 4 \text { months } \\
\text { after date of } \\
\text { order. }\end{array}$ \\
\hline 16. & $\begin{array}{l}\text { OD v R City } \\
\text { Council }\end{array}$ & $\mathrm{M}$ & 46 & $\begin{array}{l}\text { Mild learning } \\
\text { disability and } \\
\text { schizophrenia }\end{array}$ & $\begin{array}{l}\text { Sexual } \\
\text { offences }\end{array}$ & Psychiatry & Written report & Unknown & $\begin{array}{l}\text { Order that OD } \\
\text { lacks capacity to: } \\
\text { decide on care, } \\
\text { residence and } \\
\text { contact. }\end{array}$ \\
\hline 17. & $\begin{array}{l}\text { P County } \\
\text { Council v (1) } \\
\text { SE (2) TM }\end{array}$ & $F$ & 80 & Dementia & $\begin{array}{l}\text { Domestic } \\
\text { abuse }\end{array}$ & Psychiatry & Written report & $\begin{array}{l}\text { Independent } \\
\text { social work } \\
\text { Independent } \\
\text { Mental Capacity } \\
\text { Advocate }\end{array}$ & $\begin{array}{l}\text { Final order. SE } \\
\text { lacks capacity to: } \\
\text { conduct } \\
\text { proceedings, } \\
\text { make decisions } \\
\text { about care and }\end{array}$ \\
\hline
\end{tabular}




\begin{tabular}{|c|c|c|c|c|c|c|c|c|c|}
\hline & & & & & & & & & $\begin{array}{l}\text { residence and } \\
\text { manage her } \\
\text { property and } \\
\text { affairs. Capacity } \\
\text { evidence } \\
\text { indicated she } \\
\text { does not lack } \\
\text { capacity to } \\
\text { decide on } \\
\text { contact and } \\
\text { sexual relations. }\end{array}$ \\
\hline 18. & $\begin{array}{l}V \text { Borough } \\
\text { Council } v A Y\end{array}$ & $M$ & 35 & $\begin{array}{l}\text { Significant } \\
\text { learning } \\
\text { disability, } \\
\text { autism and } \\
\text { sensory } \\
\text { processing } \\
\text { disorder }\end{array}$ & $\begin{array}{l}\text { Domestic } \\
\text { abuse }\end{array}$ & None & $\mathrm{N} / \mathrm{A}$ & $\begin{array}{l}\text { Social work (by } \\
\text { way of statement } \\
\text { in CoP } \\
\text { application) }\end{array}$ & $\begin{array}{l}\text { Order that AY } \\
\text { lacks capacity to: } \\
\text { decide where to } \\
\text { live and decide } \\
\text { on matters of } \\
\text { care and support. } \\
\text { Order that it is in } \\
\text { AY's best } \\
\text { interests to have } \\
\text { contact with his } \\
\text { mother and any } \\
\text { other members } \\
\text { of extended } \\
\text { family in } \\
\text { accordance with } \\
\text { wishes and } \\
\text { feelings. }\end{array}$ \\
\hline 19. & $P C C G \vee Q B$ & $\mathrm{M}$ & 43 & $\begin{array}{l}\text { Mild learning } \\
\text { disability and } \\
\text { autism }\end{array}$ & $\begin{array}{l}\text { Sexual } \\
\text { offences }\end{array}$ & Psychiatry & Written report & Unknown & $\begin{array}{l}\text { Order that QB } \\
\text { lacks capacity to: } \\
\text { litigate, decide on } \\
\text { residence and } \\
\text { care. }\end{array}$ \\
\hline
\end{tabular}




\begin{tabular}{|c|c|c|c|c|c|c|c|c|c|}
\hline & & & & & & & & & $\begin{array}{l}\text { Order that it is in } \\
\text { QB's best } \\
\text { interests to } \\
\text { reside at } \\
\text { placement and } \\
\text { receive care } \\
\text { package. Matter } \\
\text { stayed until } \\
\text { DOLS expires in } \\
2017 \text {. }\end{array}$ \\
\hline 20. & $\begin{array}{l}\text { O City } \\
\text { Council v (1) } \\
\text { AW (2) FW } \\
\text { (3) YW (4) } \\
T W\end{array}$ & $F$ & 34 & $\begin{array}{l}\text { Emotionally } \\
\text { unstable } \\
\text { personality } \\
\text { disorder, } \\
\text { borderline } \\
\text { learning } \\
\text { difficulties } \\
\text { and paranoid } \\
\text { schizophrenia }\end{array}$ & $\begin{array}{l}\text { Domestic } \\
\text { abuse } \\
\text { Sexual } \\
\text { offences }\end{array}$ & None & $\mathrm{N} / \mathrm{A}$ & $\begin{array}{l}\text { Social work (by } \\
\text { way of statement } \\
\text { in CoP } \\
\text { application) }\end{array}$ & $\begin{array}{l}\text { Final order. AW } \\
\text { lacks capacity to: } \\
\text { conduct } \\
\text { proceedings and } \\
\text { make decisions } \\
\text { about contact. } \\
\text { Order that it is in } \\
\text { P's best interests } \\
\text { not to have any } \\
\text { contact, either } \\
\text { directly or } \\
\text { indirectly, with } \\
\text { father and } \\
\text { brothers. }\end{array}$ \\
\hline
\end{tabular}

